\title{
Characterization of attached bacterial populations in deep granitic groundwater from the Stripa research mine by 165 rRNA gene sequencing and scanning electron microscopy
}

\author{
Susanne Ekendahl, Johanna Arlinger, Fredrik Ståhl† and \\ Karsten Pedersen
}

Author for correspondence: Susanne Ekendahl. Tel: +463177325 86. Fax: +46317732599. e-mail: Ekendahl@gmm.gu.se

Department of General and Marine Microbiology, University of Göteborg, Medicinaregatan 9C, S-413 90 Göteborg, Sweden
This paper presents the molecular characterization of attached bacterial populations growing in slowly flowing artesian groundwater from deep crystalline bed-rock of the Stripa mine, south central Sweden. Bacteria grew on glass slides in laminar flow reactors connected to the anoxic groundwater flowing up through tubing from two levels of a borehole, 812-820 $\mathrm{m}$ and 970-1240 $\mathrm{m}$. The glass slides were collected, the bacterial DNA was extracted and the 165 rRNA genes were amplified by PCR using primers matching universally conserved positions 519-536 and 1392-1405. The resulting PCR fragments were subsequently cloned and sequenced. The sequences were compared with each other and with 16S rRNA gene sequences in the EMBL database. Three major groups of bacteria were found. Signature bases placed the clones in the appropriate systematic groups. All belonged to the proteobacterial groups beta and gamma. One group was found only at the $812-820 \mathrm{~m}$ level, where it constituted $63 \%$ of the sequenced clones, whereas the second group existed almost exclusively at the 970-1240 m level, where it constituted $83 \%$ of the sequenced clones. The third group was equally distributed between the levels. A few other bacteria were also found. None of the 165 rRNA genes from the dominant bacteria showed more than $88 \%$ similarity to any of the others, and none of them resembled anything in the database by more than $96 \%$. Temperature did not seem to have any effect on species composition at the deeper level. SEM images showed rods appearing in microcolonies. The conditions at the levels differ in $\mathrm{pH}$, temperature, redox and flow rate, and in content of sulphate, iron and sulphide. The presence of one dominant species in the laminar-flow reactors at each level indicates that the environments might have offered restrictive physical or physiological conditions difficult to adapt to.

Keywords: deep groundwater, attached bacteria, Stripa, 16S rRNA, scanning electron microscopy

\section{INTRODUCTION}

The deep subterranean environment is a relatively new area for microbiological research. The number of papers

\footnotetext{
†Present address: Department of Genetics, University of Göteborg, Medicinaregatan 9C, S-41390 Göteborg, Sweden.

Abbreviations: AODC, acridine orange direct counts; SEM, scanning electron microscopy.

The EMBL and GenBank accession numbers for the nucleotide sequences of the three dominant groups I, II and III (see text) are L20810, L20811 and L20812, respectively.
}

dealing with the deep groundwaters has increased during the last ten years (Pedersen, 1993a). Groundwaters often offer nutrient-poor conditions, yet bacteria have been found deep down below the ground surface (Pedersen, 1993a; Pedersen \& Ekendahl, 1990, 1992a, b). They attract scientific attention for several reasons, such as drinking water contamination problems, toxic waste dumps and the storage of nuclear waste deep underground (Pedersen, 1993b, West et al., 1982, 1985).

Deep granitic rock with groundwater, fractures and 
minerals has been suggested as a suitable place for the storage of high-level nuclear waste in Sweden, where this kind of bed-rock is very common. A typical such granite rock formation lies around the former iron ore Stripa research mine in south central Sweden. The iron ore consists of a quartz-banded haematite in a lepatite formation and was mined out in 1976 (Nordström et al., 1985). We have in earlier studies observed that bacteria existed down to $1240 \mathrm{~m}$ below ground in a borehole in this mine, that there would be from $4 \times 10^{3}$ to $8 \times 10^{5}$ more attached than unattached bacteria in a fracture channel and that the attached bacteria were more active than the unattached bacteria (Ekendahl \& Pedersen, 1994; Pedersen \& Ekendahl, 1992a).

In this study we used the 16S rRNA gene sequencing technique to characterize the Stripa populations attached to glass slides. Results from enrichment cultures of these bacteria and studies of the populations by scanning: electron microscopy (SEM) are also reported. Our aim. was to identify dominant bacterial species or groups in the populations. The overall distribution of bacteria and the dominant attached groups at each of two levels of the selected borehole are described.

\section{METHODS}

Study site and sampling of attached bacteria. The Stripa mine, the borehole V2, the groundwater and the attachment and growth of bacteria on glass slides in laminar-flow reactors are described in the preceding paper (Ekendahl \& Pedersen, 1994). The reactors (Pedersen, 1982; Pedersen et al., 1986) were placed in a mine drift $410 \mathrm{~m}$ below ground and connected to the flowing groundwaters from the borehole levels $812-820 \mathrm{~m}$ $\left(10^{\circ} \mathrm{C}, 2.8 \times 10^{-3} \mathrm{~m} \mathrm{~s}^{-1}\right)$ and $970-1240 \mathrm{~m}\left(10^{\circ} \mathrm{C}\right.$ and $20^{\circ} \mathrm{C}$, $\left.0.5 \times 10^{-3} \mathrm{~m} \mathrm{~s}^{-1}\right)$. Slides from these reactors were sampled after 161 and $71 \mathrm{~d}$, respectively, immersed in $0.22 \mu \mathrm{m}$ filtered groundwater, and transported on dry ice to the laboratory, where the groundwater was decanted from the slides and stored at $-80^{\circ} \mathrm{C}$ until DNA extraction.

SEM studies of attached bacteria. Microscope slides with attached bacteria were sampled and immersed in groundwater as above, fixed in glutaraldehyde, dehydrated with alcohol/ acetone, critical-point dried, sputtered with gold/palladium and observed in a Zeiss DSM 940 scanning electron microscope.

Enrichment cultures. Sterile $100 \mathrm{ml}$ serum bottles were provided with a medium of $0.5 \mathrm{ml} 3.5 \mathrm{M}$ sodium lactate, $10 \mathrm{ml}$ $350 \mathrm{mM}$ sodium sulphate and $5 \mathrm{mg}$ sodium dithionite, and with solutions of $60 \mu \mathrm{l}$ trace elements, $60 \mu \mathrm{l}$ selenite and tungstate, $30 \mu \mathrm{l}$ mixed vitamins and $60 \mu \mathrm{l}$ vitamin $\mathrm{B}_{12}$ described elsewhere (Pedersen \& Ekendahl, 1990). Ten bottles for each level and temperature were supplied with $50 \mathrm{ml}$ sterile filtered alkaline groundwater under $\mathrm{N}_{2}$. Sterile wooden sticks were used to rub attached bacteria off slides from the reactors and immediately put into the bottles, which were closed with butyl rubber stoppers and stored at room temperature. Sterile glass beads (diameter $5 \mathrm{~mm}$ ) were added to some of the bottles to increase the surface area for attached growth.

On a subsequent occasion, the same type of enrichment cultures were made, but this time $10 \mathrm{ml}$ of either a borax $/ \mathrm{NaOH}$ buffer $(\mathrm{pH} \mathrm{10})$ or a carbonate buffer $(\mathrm{pH} \mathrm{10})$ was added to each bottle to keep $\mathrm{pH}$ constant. Also, $0 \cdot 1-0 \cdot 2 \mathrm{ml} \mathrm{Na} \mathrm{N}_{2} \mathrm{~S}(0 \cdot 37 \mathrm{M})$ was added to keep redox low and stable.

In another set of enrichments, a medium consisting of $300 \mathrm{ml}$ deionized water, $9 \mathrm{ml}$ sodium lactate, $60 \mathrm{ml}$ sodium sulphate, solutions of $0.9 \mathrm{ml}$ trace elements and $0.9 \mathrm{ml}$ selenite and tungstate was adjusted to $\mathrm{pH} 10$ and autoclaved. Concentrations were the same as above. The medium was added in $5 \mathrm{ml}$ portions to each of 30 sterile nitrogen-filled Hungate tubes, to which $0.15 \mathrm{~g}$ agar (hochrein) was added and mixed at $+60^{\circ} \mathrm{C}$. The tubes were closed with butyl rubber stoppers and cooled. In the mine, the agar medium was melted and the tubes then heated in a $+40{ }^{\circ} \mathrm{C}$ water bath. Ten $\mathrm{ml}$ flowing groundwater from $812-820 \mathrm{~m}$ was added to some tubes for culturing bacteria from the water phase. The groundwater was Dynagard-filtered into other tubes under $\mathrm{N}_{2}$. Pieces of $20 \mathrm{~mm}$ glass slides from a $812-820 \mathrm{~m}$ reactor were put into the agar of these tubes to culture attached bacteria. The tubes were cooled and stored at room temperature in the dark.

DNA extraction. Our protocol for DNA extraction was based on procedures described by Marmur (1961) and Wallace (1987), but was slightly modified. Glass slides, $40 \times 24 \mathrm{~mm}$, from the freezer were thawed and crushed into smaller pieces by putting pressure on the edge of each slide with sterile glass stirrers. The pieces were put in $760 \mu \mathrm{l} 20 \mathrm{mM}$ Tris/ $\mathrm{HCl}, \mathrm{pH} 8 \cdot 0,20 \mathrm{mM}$ EDTA, $0.35 \mathrm{M}$ sucrose and incubated with lysozyme $\left(2 \mathrm{mg} \mathrm{ml}^{-1}\right.$; Sigma) at $37^{\circ} \mathrm{C}$ for $1 \mathrm{~h}$ to destroy cell walls. Then, the attached cells were lysed by adding $40 \mu \mathrm{l} 20 \%$ (w/v) SDS and the proteins digested with proteinase $\mathrm{K}\left(250 \mu \mathrm{g} \mathrm{ml}^{-1}\right.$; Sigma) during an additional incubation at $60^{\circ} \mathrm{C}$ for $1 \mathrm{~h}$. The DNA was extracted from $400 \mu$ l of the cell lysate solution with an equal volume of phenol/chloroform/isoamyl alcohol $(25: 24: 1$, by vol.), followed by one extraction with chloroform/isoamyl alcohol ('chisam', 24:1) so that no cell debris was visible. Finally the 'chisam' was washed with TE buffer $(10 \mathrm{mM}$ Tris $/ \mathrm{HCl}, 1 \mathrm{mM}$ EDTA, $\mathrm{pH} 8 \cdot 0)$. The DNA was precipitated with $1 / 3$ vol. $10 \mathrm{M}$ ammonium acetate (final concn $2.5 \mathrm{M}$ ) and 2.5 vols $99 \%(\mathrm{v} / \mathrm{v})$ ethanol. To ensure complete recovery, $50 \mu \mathrm{g}$ tRNA was added as a carrier. The precipitate was washed with $100 \mu \mathrm{l} 70 \%$ ethanol and dried in vacuum for $30 \mathrm{~s}$, dissolved in TE buffer and stored at $-20^{\circ} \mathrm{C}$. This procedure was repeated once for each borehole level and temperature.

To obtain a representative material, all cells on the glass slides must be disrupted in the initial lysis steps. The degree of this cell disruption was measured by staining the slides with acridine orange after lysis as described for total direct counts (Pedersen \& Ekendahl, 1990). They were inspected for potential unlysed cells under blue light $(390-490 \mathrm{~nm})$ in an epifluorescence microscope (Zeiss, filter $515 \mathrm{~nm}$ ) at $1250 \times$ enlargement. No cells were detected, indicating complete cell lysis. Additional control experiments with lysis of cell suspensions of Escbericbia coli, Desulfomicrobium baculatum and Bacillus megaterium showed that $90-95 \%$ of the cells were lysed with this method.

PCR amplification and purification of the product. One microlitre of the extracted DNA solution was sufficient to amplify the $16 \mathrm{~S}$ rRNA region by PCR (Saike et al., 1988). The DNA was added to a mixture of $10 \mu \mathrm{l}$ of $10 \times$ PCR buffer (Stratagene), $0.2 \mathrm{mM}$ of each nucleotide triphosphate, $0.25 \mu \mathrm{M}$ of each primer and double-distilled water to a final volume of $100 \mu \mathrm{l}$. The samples were first treated with RNase A (10 $\mathrm{mg} \mathrm{ml}^{-1}$; Sigma) for $15 \mathrm{~min}$ at $37^{\circ} \mathrm{C}$ and then incubated at $95{ }^{\circ} \mathrm{C}$ for $5 \mathrm{~min}$, before addition of $1 \mu \mathrm{l}$ Pfu DNA polymerase 
(Stratagene) and coating with $100 \mu \mathrm{l}$ mineral oil (Sigma). A total of 30 cycles were performed at $95^{\circ} \mathrm{C}(30 \mathrm{~s}), 55^{\circ} \mathrm{C}(1 \mathrm{~min}), 72^{\circ} \mathrm{C}$ ( $2 \mathrm{~min}$ ) followed by a final incubation at $72^{\circ} \mathrm{C}$ for $10 \mathrm{~min}$.

The $5^{\prime}$ and $3^{\prime}$ primers used matched the universally conserved positions 519-536 and 1392-1405 (E. coli Brosius numbering: Brosius et al., 1978). These were chosen to ensure that eubacterial, archaeobacterial and eventually eukaryotic species could be amplified. To facilitate cloning, a SacII restriction enzyme site was synthesized at the $5^{\prime}$ end of the 1405-1392 primer, by adding six bases to the conservative sequence (Hallbeck et al., 1993). The 519-536 primer sequence already contains a SacII site (Hallbeck et al., 1993), so this sequence was kept unchanged except for two bases added at the $5^{\prime}$ end to make both primers equal in size and purine/pyrimidine composition.

The amplification products were purified with the QIAEX agarose extraction kit (Qiagen), following the specification of the manufacturer, and were finally diluted in $20 \mu \mathrm{l}$ doubledistilled water and stored at $-20^{\circ} \mathrm{C}$.

Cloning. The purified samples were digested with SacII (Boehringer Mannheim) in a solution consisting of 16-19 $\mu \mathrm{l}$ (100-350 ng) DNA, $10 \% 10 \times$ RM buffer, $2-4 \mu \mathrm{l}$ SacII and double-distilled water to a final volume of $50 \mu$ l. The incubation was performed at $37^{\circ} \mathrm{C}$ for $2 \mathrm{~h}$ and stopped at $65^{\circ} \mathrm{C}$ for $15 \mathrm{~min}$. The samples were purified once more with QIAEX and then the DNA was ligated with a pBluescript SK vector (Stratagene) using standard methods (Maniatis et al., 1982). The vector was also SacII-digested and treated with calf intestine phosphatase (CIP, Boehringer Mannheim) to prevent self ligation. The molar ratio between DNA insert and the vector was $1: 1$ or $2: 1$. The ligation mixture consisted of $1 \mu \mathrm{l}(100 \mathrm{ng}) \mathrm{pSK}, 1$ or $2 \mu \mathrm{l}$ (30-65 ng) insert, $0.5 \mu \mathrm{l} 10 \times \mathrm{RM}$ buffer, $0.3 \mu \mathrm{l} \mathrm{T} 4$ DNA ligase (Boehringer Mannheim) and double-distilled water to a final volume of $5 \mu \mathrm{l}$. The incubation was performed overnight at $+4^{\circ} \mathrm{C}$.

The ligated products were transformed into $10 \%(\mathrm{v} / \mathrm{v})$ glycerol washed E. coli (XL1blue, Stratagene) by electroporation (BioRad). From each transformation, 50 or $100 \mu$ l was spread on Luria Broth agar plates which contained 1/500 vol. ampicillin $\left(25 \mathrm{mg} \mathrm{ml}^{-1}\right.$ ) and had been coated with $60 \mu \mathrm{l} 2 \% \mathrm{X}-\mathrm{Gal}$ and $40 \mu \mathrm{l} 100 \mathrm{mM}$ IPTG $30 \mathrm{~min}$ before spreading. They were incubated overnight at $37^{\circ} \mathrm{C}$ in the dark. From each DNA extraction, a total of 30 white colonies containing the insert were randomly picked out and numbered 1 to 30 . They were grown in $5 \mathrm{ml} \mathrm{LB}+$ ampicillin solution overnight at $37^{\circ} \mathrm{C}$. From each culture $0.5 \mathrm{ml}$ was suspended in $0.5 \mathrm{ml}$ conc. glycerol and stored at $-80^{\circ} \mathrm{C}$. Every third clone (12 of every 30 clones), a total of 72 clones, was picked out for subsequent sequencing. The recombinant plasmids were extracted from the bacteria with the Magic miniprep kit (Promega).

Double-stranded sequencing. The sequencing was done using the double-strand sequencing protocol of the Multi-Pol DNA sequencing system (Clontech) and standard procedures were followed. Before the actual sequencing reactions, $1-4 \mu \mathrm{g}$ of the DNA was denatured with $2 \mathrm{M} \mathrm{NaOH}$, precipitated with $3 \mathrm{M}$ sodium acetate and $99 \%$ ethanol, and washed with $70 \%$ ethanol. All clones were sequenced using the primer $907 \mathrm{r}$ (Hallbeck et al., $1993)$, run on $6 \%(\mathrm{w} / \mathrm{v})$ polyacrylamide gels and exposed to Xray film for $3 \mathrm{~d}$. The 72 sequences were compared with each other by reading directly on the films and divided into groups. Clones that were identical were put in the same group. One clone from each dominating group was fully sequenced and several different internal primers were used in these reactions, as specified in Hallbeck et al. (1993).

Control for quantitative PCR. Pure cultures of typical groundwater bacteria were harvested in the lag phase. Mixtures of 4 parts $D$. baculatum and 1 part Gallionella ferruginea at $5 \times 10^{4}$ and $1 \times 10^{6}$ cells $\mathrm{ml}^{-1}$ and of 1 part each of $B$. megaterium, $D$. baculatum and $G$. ferruginea at $1 \times 10^{4}$ and $1 \times 10^{6}$ cells ml ${ }^{-1}$ were extracted, PCR-treated, cloned and sequenced as above.

Sequence analysis. Multiple alignments and comparison with 16S rRNA genes of other organisms were made using the Genetic Computer Group (GCG) sequencing analysis and the EMBL database. The sequences were also compared with signature bases in Woese (1987) to place them into systematic groups.

\section{RESULTS \\ SEM studies}

Figs 1(a) and 1(b) show microscope slides which had been exposed to flowing groundwater from $812-820 \mathrm{~m}$ depth $\left(2 \cdot 8 \times 10^{-3} \mathrm{~m} \mathrm{~s}^{-1}\right)$ for $161 \mathrm{~d}$. A thin film that dried during SEM preparations (Fig. $1 \mathrm{~h}$ ) covered colonies of short rods, $1-2.5 \mu \mathrm{m}$, mean $2.0 \mu \mathrm{m}$. Some AODC images from this depth showed a few bacteria with an outer morphology resembling Planctomycetes (not shown). Occasionally, stalked bacteria resembling Caulobacter could be observed (Fig. 1g). Figs 1(c) and 1(d) show bacteria from $970-1240 \mathrm{~m}, 10^{\circ} \mathrm{C}$, after $71 \mathrm{~d}$ exposure. The rods were 1.5-2.5 (mean 2.2) $\mu \mathrm{m}$ long and appeared singly or in colonies. Figs $1(\mathrm{e})$ and $1(\mathrm{f})$ show bacteria from the same interval after $71 \mathrm{~d}$, but exposed to $20^{\circ} \mathrm{C}$. These rods had a mean length of $2.4 \mu \mathrm{m}$ but were sometimes filamentous (more than $5 \mu \mathrm{m}$ long). They appeared in colonies, and thin $(100 \mathrm{~nm})$ threads were present together with the bacteria.

\section{Enrichment cultures}

The attempts to cultivate the Stripa bacteria in serum bottles and agar-shakes were all unsuccessful. Two morphological types of cells could be seen when subsamples from $970-1240 \mathrm{~m}, 20^{\circ} \mathrm{C}$, were stained with acridine orange (Pedersen \& Ekendahl, 1990) and studied with epifluorescence microscopy. Some were long thin rods and others were oval in shape. The bacteria in one bottle grew to five times their original numbers during $9 \mathrm{~d}$, but did not grow any further after that. Heat shock may explain the lack of growth in the agar-shakes.

\section{Control for quantitative PCR}

Applying this technique to equal-sized bacteria (mixture 1 ), the sequences were obtained in the same proportions as in the start mixture (Table 1). When the 24 times larger $B$. megaterium was included, its DNA dominated the result.

\section{Clone groups}

The clones examined clustered into three major groups called I, II, and III (Table 2). Clones that were identical 

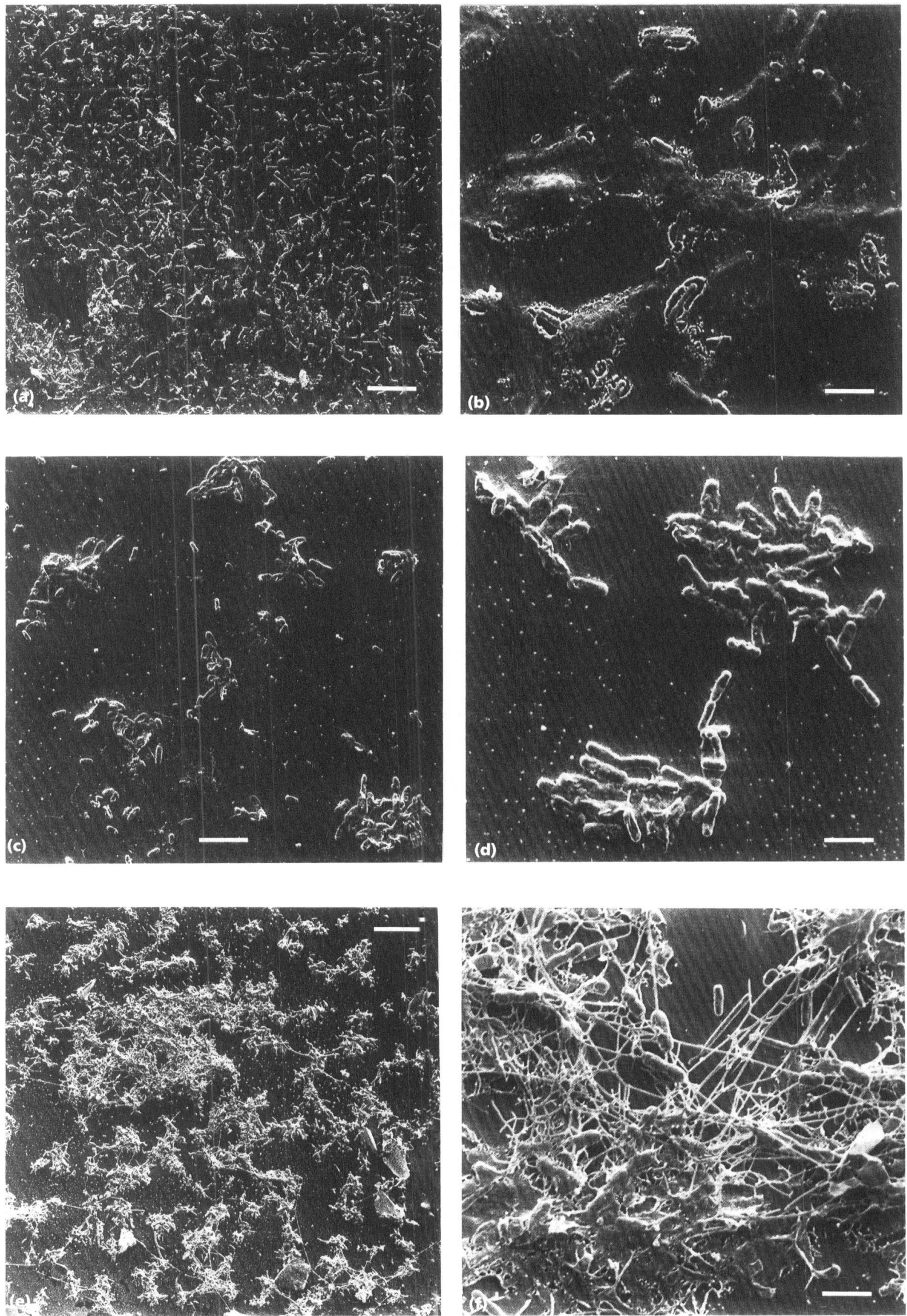

Fig. 1. For legend see facing page. 

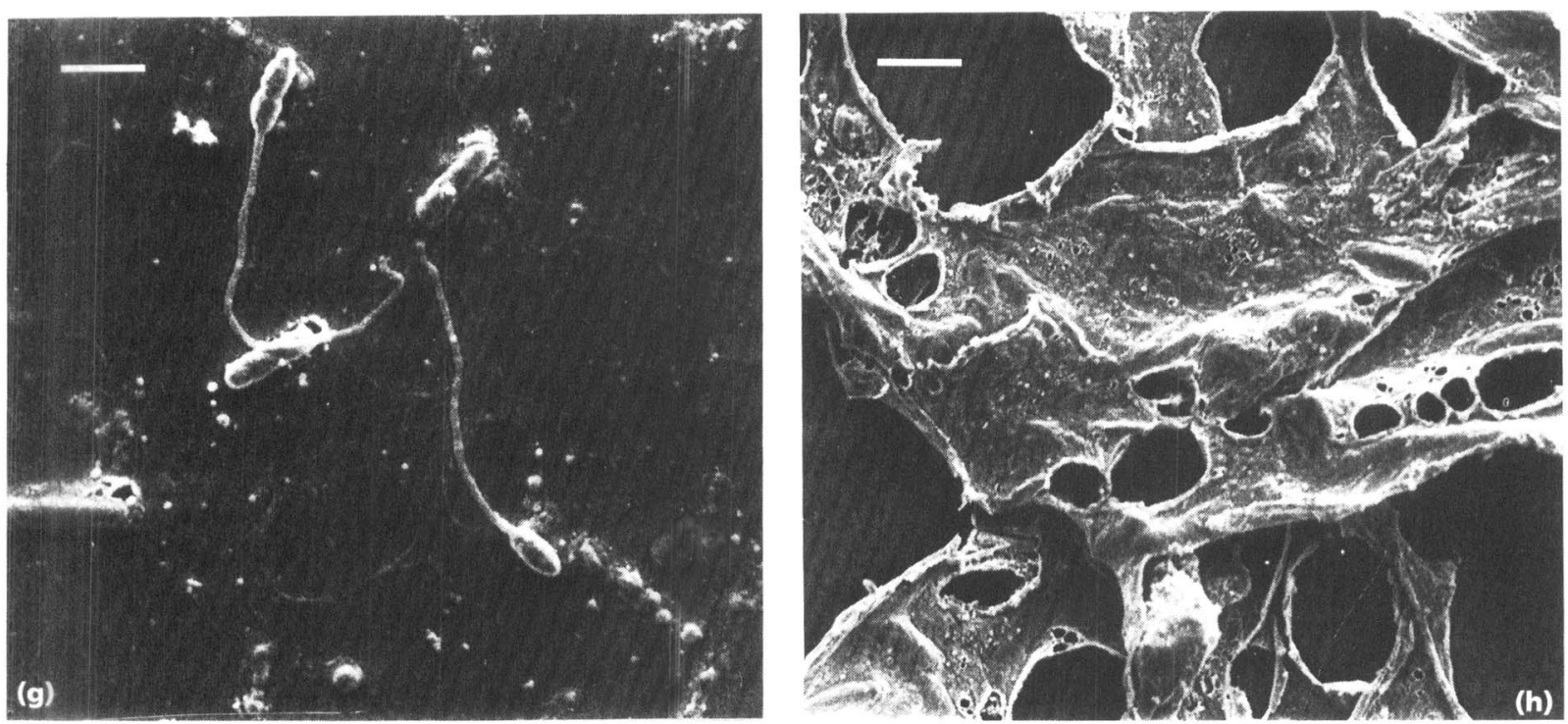

Fig. 1. SEM images of attached bacteria on microscope slides exposed to flowing groundwater from the Stripa borehole V2. (a, b) 812-820 m, $10^{\circ} \mathrm{C}, 161 \mathrm{~d}$; (c, d) $970-1240 \mathrm{~m}, 10^{\circ} \mathrm{C}, 71 \mathrm{~d}$; (e, f) $970-1240 \mathrm{~m}, 20^{\circ} \mathrm{C}, 71 \mathrm{~d} ;(\mathrm{g}, \mathrm{h}) 812-820 \mathrm{~m}, 10^{\circ} \mathrm{C}, 161 \mathrm{~d}$. Bars: (a) $20 \mu \mathrm{m}$, (b) $2 \mu \mathrm{m}$, (c) $5 \mu \mathrm{m}$, (d) $2 \mu \mathrm{m}$, (e) $20 \mu \mathrm{m}$, (f) $2 \mu \mathrm{m}$, (g) $1 \mu \mathrm{m}$, (h) $2 \mu \mathrm{m}$.

Table 1. Species distribution of 12 randomly chosen clones for two different bacterial mixtures and concentrations

Pure cultures of groundwater bacteria were harvested in the lag phase, mixed in two different proportions, their DNA extracted, PCR treated, cloned and sequenced.

\begin{tabular}{|c|c|c|c|c|}
\hline \multirow[t]{2}{*}{ Bacteria in mixture } & \multirow{2}{*}{$\begin{array}{l}\text { Cell volume } \\
\text { ratio }\end{array}$} & \multirow[t]{2}{*}{ Mixture } & \multicolumn{2}{|c|}{ Species distribution of clones at: } \\
\hline & & & $5 \times 10^{4}$ cells $\mathrm{ml}^{-1}$ & $1 \times 10^{6}$ cells ml ${ }^{-1}$ \\
\hline Mixture 1 & & & & \\
\hline $\begin{array}{l}\text { Desulfomicrobium baculatum: } \\
\text { Gallionella ferruginea }\end{array}$ & $1: 1$ & $4: 1$ & $10: 2$ & $10: 2$ \\
\hline Mixture 2 & & & & \\
\hline $\begin{array}{l}\text { Bacillus megaterium: } \\
\text { Desulfomicrobium baculatum: } \\
\text { Gallionella ferruginea }\end{array}$ & $24: 1: 1$ & $1: 1: 1$ & $11: 1: 0$ & $12: 0: 0$ \\
\hline
\end{tabular}

were placed in the same group and clones that differed from the major groups, appearing only once, were regarded as single observations. None of the clones among the single observations were identical, but some were closely related to the dominant groups, differing by only a few bases.

(i) Level $\mathbf{8 1 2 - 8 2 0 ~} \mathbf{m}$. Almost two-thirds of the clones from this level belonged to group I (Table 2). Two clones belonged to group II, and the remaining four clones $(17 \%)$ clustered in group III. Three clones were single observations. The ratio between the two extractions is close to $1: 1$ and therefore comparable.

(ii) Level 970-1240 m. Group II dominated this level at $10^{\circ} \mathrm{C}$. As much as $83 \%$ of the clones were of this type. No clones from group I were found and only one clone belonged to group III.

At $20{ }^{\circ} \mathrm{C}, 13$ clones $(54 \%)$, belonged to group II, none to group I, and four to group III. Four of the seven clones that were single observations did not show much resemblance to any other sequences. Since these four clones were found only in the first DNA extraction and two of them were related to eukaryotes, one of them showing $100 \%$ similarity to human chromosomal DNA, we suspected that this extraction was contaminated in the laboratory. These four clones are therefore not considered further.

The ratio of clones between the two extractions was close to $1: 1$ at both 10 and $20^{\circ} \mathrm{C}$. The distribution of clones 
Table 2. Groups of bacterial clones screened from two levels of the Stripa borehole V2 and their distribution

DNA from bacteria attached to glass surfaces was extracted, and the $16 \mathrm{~S}$ rRNA genes were amplified by PCR, cloned and sequenced using primer 907-926. Each of the groups I, II and III contains identical clones. Single observations were not identical.

\begin{tabular}{|c|c|c|c|c|c|c|}
\hline \multirow{2}{*}{$\begin{array}{l}\text { Clone } \\
\text { group }\end{array}$} & \multicolumn{2}{|c|}{$812-820 \mathrm{~m}, 10^{\circ} \mathrm{C}$} & \multicolumn{2}{|c|}{$970-1240 \mathrm{~m}, 10^{\circ} \mathrm{C}$} & \multicolumn{2}{|c|}{$970-1240 \mathrm{~m}, 20^{\circ} \mathrm{C}$} \\
\hline & $\begin{array}{l}\text { No. of } \\
\text { clones* }\end{array}$ & $\begin{array}{l}\% \text { of } \\
\text { total }\end{array}$ & $\begin{array}{l}\text { No. of } \\
\text { clones* }\end{array}$ & $\begin{array}{l}\% \text { of } \\
\text { total }\end{array}$ & $\begin{array}{l}\text { No. of } \\
\text { clones* }\end{array}$ & $\begin{array}{l}\% \text { of } \\
\text { total }\end{array}$ \\
\hline I & $15(6+9)$ & 63 & $0(0+0)$ & 0 & $0(0+0)$ & 0 \\
\hline II & $2(2+0)$ & 8 & $20(10+10)$ & 83 & $13(5+8)$ & 54 \\
\hline III & $4(2+2)$ & 17 & $1(1+0)$ & 4 & $4(2+2)$ & 17 \\
\hline $\begin{array}{l}\text { Single } \\
\text { observations }\end{array}$ & $3(2+1)$ & 12 & $3(1+2)$ & 12 & $7(5 \dagger+2)$ & 29 \\
\hline
\end{tabular}

* The total number of clones in each clone group is followed, in parentheses, by the numbers achieved in extraction 1 and 2, respectively.

†Four of these clones are probably due to contamination, see text for details.

Table 3. Comparison of similarity between the sequenced Stripa clone groups and 16S rRNA sequences in the EMBL database

\begin{tabular}{|lcclll|}
\hline $\begin{array}{c}\text { Clone } \\
\text { group }\end{array}$ & $\begin{array}{c}\text { EMBL } \\
\text { accession } \\
\text { no. }\end{array}$ & $\begin{array}{c}\text { Overlap, } \\
\text { no. of bp } \\
\text { compared* }\end{array}$ & Systematic groupt & Most related bacteria & $\begin{array}{c}\% \\
\text { similarity }\end{array}$ \\
\hline I & L20810 & 764 & Beta Proteobacteria & Pseudomonas solanacearum & $91 \cdot 7$ \\
II & L20811 & 877 & Beta-1 Proteobacteria & Pseudomonas testosteroni & $91 \cdot 2$ \\
& & 877 & & Brachymonas denitrificans & $94 \cdot 9$ \\
III & L20812 & 739 & Gamma Proteobacteria & Acinetobacter calcoaceticus & $96 \cdot 1$ \\
& & 737 & & Pseudomonas aeruginosa & $87 \cdot 7$ \\
\hline
\end{tabular}

* Between the clone and the most related bacterium.

† According to signature bases in Woese (1987).

between the two temperatures at this level is also comparable if the four contaminants are excluded. Due to their exclusion, the percentage of the group II bacteria at $20{ }^{\circ} \mathrm{C}$ rises to $65 \%$, group III to $20 \%$ and the single observations decrease to $15 \%$ of the total number of clones at $20^{\circ} \mathrm{C}$ (compare Table 2 ).

\section{Phylogenetic relationships}

Comparison of the fully sequenced clone from group I with signature bases (Woese, 1987) placed it among the beta group of the Proteobacteria, as shown in Table 3. This group was found only at the $812-820 \mathrm{~m}$ level and the highest percentages of similarity were found with the bacteria Pseudomonas solanaceum $(91.7 \%)$ and Zoogloea ramigera $(91 \cdot 2 \%)$.

Except for two clones from the $812-820 \mathrm{~m}$ level, group II was found to exist and dominate at the 970-1240 $\mathrm{m}$ level, at both temperatures. This group fell into the beta-1 group of the Proteobacteria and the highest percentages of similarity were found with Pseudomonas testosteroni $(95.9 \%)$ and Bracbymonas denitrificans $(94.9 \%)$.

Group III was found at both levels in comparable frequencies. This group belonged to the gamma group of the Proteobacteria and showed highest similarities with Acinetobacter calcoaceticus $(96.1 \%)$ and Pseudomonas aeruginosa $(87 \cdot 7 \%)$.

Comparing the whole bacterial sequences from the three major groups with each other (Table 4) showed that the highest percentage of similarity $(88.4 \%)$ was found between groups I and II. Comparisons between the most related bacteria for each group are also included in this table. 
Table 4. Similarity values (\%) between 165 rRNA gene sequenced Stripa clones and closely related bacteria from the EMBL database

\begin{tabular}{|c|c|c|c|c|c|c|c|c|c|}
\hline & I & II & III & 1 & 2 & 3 & 4 & 5 & 6 \\
\hline I & $100 \cdot 0$ & $88 \cdot 4$ & $82 \cdot 2$ & $91 \cdot 7$ & $91 \cdot 2$ & $89 \cdot 2$ & $90 \cdot 4$ & $82 \cdot 7$ & $84 \cdot 8$ \\
\hline II & & $100 \cdot 0$ & $80 \cdot 3$ & $88 \cdot 6$ & $91 \cdot 9$ & $95 \cdot 9$ & $94 \cdot 9$ & $82 \cdot 1$ & $85 \cdot 0$ \\
\hline III & & & $100 \cdot 0$ & $83 \cdot 0$ & $84 \cdot 4$ & $81 \cdot 9$ & $81 \cdot 8$ & $96 \cdot 1$ & $87 \cdot 7$ \\
\hline $\begin{array}{c}\text { 1. Pseudomonas } \\
\text { solanaceum }\end{array}$ & & & & $100 \cdot 0$ & $91 \cdot 2$ & $88 \cdot 2$ & $89 \cdot 3$ & $83 \cdot 4$ & $84 \cdot 2$ \\
\hline $\begin{array}{l}\text { 2. Zoogloea } \\
\text { ramigera }\end{array}$ & & & & & $00 \cdot 0$ & $88 \cdot 3$ & $88 \cdot 2$ & $84 \cdot 6$ & $84 \cdot 7$ \\
\hline $\begin{array}{r}\text { 3. Pseudomonas } \\
\text { testosteroni }\end{array}$ & & & & & & $00 \cdot 0$ & $94 \cdot 7$ & $81 \cdot 7$ & $83 \cdot 0$ \\
\hline $\begin{array}{r}\text { 4racbymonas } \\
\text { denitrificans }\end{array}$ & & & & & & & $100 \cdot 0$ & $81 \cdot 5$ & $83 \cdot 4$ \\
\hline $\begin{array}{l}\text { 5. Acinetobacter } \\
\text { calcoaceticus }\end{array}$ & & & & & & & & $100 \cdot 0$ & $88 \cdot 1$ \\
\hline $\begin{array}{c}\text { 6. Pseudomonas } \\
\text { aeruginosa }\end{array}$ & & & & & & & & & $100 \cdot 0$ \\
\hline
\end{tabular}

\section{DISCUSSION}

Knowledge of the bacterial species present in an ecological system is of interest to evaluate the specific properties and functions of the system. Good methods for enumeration and identification of these species or groups are necessary. All attempts to enrich and grow the viable (Pedersen \& Ekendahl, 1992a) Stripa bacteria failed. Earlier attempts to culture them on plate count growth media for heterotrophs with and without oxygen resulted in less than $1 \%$ of the total population growing (Pedersen 1988). The negative plate count and enrichment results emphasize the importance of methods in microbial ecology that are independent of laboratory culturing techniques. In this study we have used a molecular method that can reveal both cultivable and uncultivable bacteria in deep groundwater. We regard our results as a fairly accurate reflection of the actual distribution of different bacterial cells in the original samples, based on the following discussion.

We used PCR for amplifying rRNA genes from mixed natural populations, being aware that archaeobacteria are reported to have usually single copies of the rRNA gene, while eubacteria commonly have $5-10$ copies per haploid genome (Davies \& Nomura, 1972; Pace et al., 1986; Ward et al., 1992). The control experiment for quantitative PCR (Table 1) indicated that the PCR technique used was quantitative for populations with equal-sized non-growing bacteria in addition to its qualitative nature, but biased when bacteria of different sizes were investigated. This result indicates that bacteria may have rRNA gene copies per genome in relation to their size, which seems reasonable. The transcription activity per rRNA gene locus under defined growth conditions will then be approximately constant and independent of large differences in size for bacteria with similar growth kinetics and comparable growth rates. The Stripa populations were very slow-growing (Ekendahl \& Pedersen, 1994) and very probably in a one-genome state.

To get the gene abundance for a particular species, one should multiply the number of cells of the studied species with the number of rRNA gene copies per cell (Ward $e t$ al., 1992). The specific/total rRNA gene ratios achieved in this study are thus an approximate and not an absolute estimate of cell numbers, but they are more accurate for estimating organism abundance than the rRNA ratios. In our study we did not detect any archaeobacteria, and the size distribution of the investigated bacteria was equal in the different samples (Ekendahl \& Pedersen, 1994), which indicates the clone distribution results to be an accurate approximation of the relative species abundance (cf. Table 2 and Fig. 3 in Ekendahl \& Pedersen, 1994).

All of the bacteria found belonged to the Proteobacteria. Two of the major groups fell into the beta group of Proteobacteria and the third into the gamma group. None of the sequences from the three groups was identical to any of the bacteria in the EMBL database. The similarity values obtained between the clone groups and the bacteria in the database are far too remote to make comparisons of their phenotypic characters reasonable (Tables 2-4). Several of the single observations showed close relation to the dominant groups, differing by only a few bases. Thus the dominant groups may have even greater importance in their ecological impact. The activities of these bacteria are discussed extensively by Ekendahl \& Pedersen (1994).

Our SEM images of the glass surfaces indicated that the two levels in the borehole had populations that were different. The bacteria were mostly rods, and differed only slightly in size between the levels (Fig. 1). Within the deeper level, the bacteria at $20^{\circ} \mathrm{C}$ had a different 
morphology from those at $10{ }^{\circ} \mathrm{C}$. They seemed to have secreted thin threads that might act as holdfasts or for cell cell interactions (Fig. 1e, f). The threads might be extracellular material that covered the whole colonies but dried during SEM dehydration (Fig. 1h), but this seems less probable if judged from the images.

The 16S gene data (Table 2) support the SEM observations that there were different populations at the two levels. The beta Proteobacteria in group I were found only at the higher level in the borehole, whereas the beta Proteobacteria in group II were found almost exclusively at the deeper level. Two clones from group II were, however, found at the higher level. As shown elsewhere, the conditions at the levels differ in $\mathrm{pH}$, temperature, redox and flow rate, and in content of sulphate, sulphide and total inorganic carbon (Ekendahl \& Pedersen, 1994). The numbers of bacteria in the bulk water phase, the $\mathrm{CO}_{2}$ assimilation and lactate respiration rates on glass slides were higher at the deeper level. The gamma Proteobacteria in group III seem to be equally distributed. The different temperatures at the deeper level had very little effect on species composition, though there was a slight indication that group II bacteria thrive better at 10 than at $20^{\circ} \mathrm{C}$ at the $970-1240 \mathrm{~m}$ level. An increase in temperature thus affected the morphology (Fig. 1) but not the population composition. The bacterial groups present may thus be selectively adapted to these different environments. For example, it can be speculated that since there was a high redox value and traces of oxygen at $812--820 \mathrm{~m}$, the group I bacteria dominating this level may be more adapted to a facultative anaerobic metabolism, while the group II bacteria are perhaps obligate anaerobes that instead will thrive in the anoxic, sulphide-rich, low-redox groundwater at 970-1240 m. The presence of one dominant species in the laminar-flow reactors at each level suggests that the environment may have offered restrictive physical or physiological conditions, difficult to adapt to. The situation in the rock is probably similar, with only a few dominant bacteria present (cf. Ekendahl \& Pedersen, 1994).

To make the description of bacterial populations in natural ecosystems complete and to reliably identify and characterize environmental samples, both genotypic and phenotypic characterization must be used in polyphasic taxonomy. Combining studies on physiology (Ekendahl \& Pedersen, 1994), morphology, and the molecular composition of deep groundwater populations, with methods like labelling and scintillation counts, SEM and sequencing, has revealed new information about deep granitic groundwater microbial ecosystems (Ekendahl \& Pedersen, 1994; Pedersen \& Ekendahl, 1992a, b). The study presented here strongly confirms our theory that there is a pronounced spatial distribution of bacteria between sampling sites as a function of environmental conditions. We have now continued our investigations on bacterial populations in deep granitic bed-rock at the Äspö Hard Rock Laboratory (Gustafsson et al., 1988, $1989,1991)$, which is under construction on the southeast coast of Sweden. Preliminary results confirm a pronounced spatial distribution of subterranean bacteria, also reported from other sites (Pedersen, 1993a). The results also suggest that in some cases the distribution of bacterial populations on glass slides is similar to the distribution of unattached bacteria in the groundwater, in other cases it is different. With the use of the techniques discussed above and also other techniques, like fluorescent molecular probes and anaerobic viable counts to quantify bacterial species in situ, we continue to investigate the structure of deep groundwater populations, what governs their existence and activity, and also what effect they may have on the surrounding environment.

\section{ACKNOWLEDGEMENTS}

We wish to thank our collaborators at the Stripa mine, Birger Ekstrand and Gunnar Ramqvist, and Tudlik Bergqvist for help with the SEM images. This work was supported by the Swedish Nuclear Fuel and Waste Management Co., the Royal Swedish Academy of Sciences, the Wilhelm och Martina Lundgren Foundation and the Adlerbertska Research Fund.

\section{REFERENCES}

Brosius, J., Palmer, M. L., Kennedy, P. J. \& Noller, H. F. (1978). Complete nucleotide sequence of a ribosomal RNA gene from Escherichia coli. Proc Natl Acad Sci US A 75, 4801-4805.

Davies, J. \& Nomura, M. (1972). The genetics of bacterial ribosomes. Annu Rev Genet 6, 203-234.

Ekendahl, S. \& Pedersen, K. (1994). Carbon transformations by attached bacterial populations in groundwater from the deep crystalline bed-rock of the Stripa research mine. Microbiology 140 , 1565-1573.

Gustafsson, G., Stanfors, R. \& Wikberg, P. (1988). Swedish Hard Rock Laboratory. First evaluation of preinvestigations 1986-1987 and target area characterization. SKB Technical Report 88-16. Available from SKB, Swedish Nuclear Fuel and Waste Management Co., Box 5864, S-10248 Stockholm.

Gustafsson, G., Stanfors, R. \& Wikberg, P. (1989). Swedish Hard Rock Laboratory. First evaluation of preinvestigations 1988 and target area characterization. SKB Technical Report 89-16. Available from SKB, Box 5864, S-10248 Stockholm.

Gustafsson, G., Liedholm, M., Rhén, I., Stanfors, R. \& Wikberg, P. (1991). Äspö Hard Rock Laboratory. Predictions prior to excavation and the process of their validation. SKB Tecbnical Report 91-23. Available from SKB, Box 5864, S-10248 Stockholm.

Hallbeck, L., Ståhl, F. \& Pedersen, K. (1993). Phylogeny and phenotypic characterization of the stalk-forming and iron-oxidizing bacterium Gallionella ferruginea. J Gen Microbiol 139, 1531-1535.

Maniatis, T. E., Fritsch, E. F. \& Sambrook, J. (1982). Molecular Cloning: a Laboratory Manual. Cold Spring Harbor, NY: Cold Spring Harbor Laboratory.

Marmur, J. A. (1961). A procedure for the isolation of deoxyribonucleic acid from microorganisms. J Mol Biol 3, 208-218.

Nordström, D. K., Andrews, J. N., Carlsson, L., Fontes, J.-C., Fritz, P., Moser, H. \& Olsson, T. (1985). Hydrogeological and hydrogeochemical investigations in boreholes -- final report of the phase 1 geochemical investigations of the Stripa groundwaters. SKB Technical Report 85-06. Swedish Nuclear Fuel and Waste Management Co., Box 5864, S-10248 Stockholm.

Pace, N. R., Stahl, D. A., Lane, D. J. \& Olsen, G. J. (1986). The 
analysis of natural microbial populations by ribosomal RNA sequence. Adv Microb Ecol 9, 1-55.

Pedersen, K. (1982). Method for studying microbial biofilms in flowing-water systems. Appl Environ Microbiol 43, 6-13.

Pedersen, K. (1988). Preliminary investigations of deep groundwater microbiology in Swedish granitic rock. SKB Technical Report 88-01. Swedish Nuclear Fuel and Waste Management Co., Box 5864, S-10248 Stockholm.

Pedersen, K. (1993a). The deep subterranean biosphere. J Earth Sci Rev 34, 243-260.

Pedersen, K. (1993b). Bacterial processes in nuclear waste disposal. Microbiol Eur 1 (no. 2) 18-23.

Pedersen, K. \& Ekendahl, S. (1990). Distribution and activity of bacteria in deep granitic groundwaters of southeastern Sweden. Microb Ecol 20, 37-52.

Pedersen, K. \& Ekendahl, S. (1992a). Incorporation of $\mathrm{CO}_{2}$ and introduced organic compounds by bacterial populations in groundwater from the deep crystalline bed-rock of the Stripa mine. J Gen Microbiol 138, 369-376.

Pedersen, K. \& Ekendahl, S. (1992b). Assimilation of $\mathrm{CO}_{2}$ and introduced organic compounds by bacterial communities in groundwater from Southeastern Sweden deep crystalline bed-rock. Microb Ecol 23, 1-14.

Pedersen, K., Holmström, C., Olsson, A.-K. \& Pedersen, A. (1986).
Statistic evaluation of the influence of species variation, culture conditions, surface wettability and fluid shear on attachment and biofilm development of marine bacteria. Arch Microbiol 145, 1-8.

Saike, R. T., Gelfand, D. H., Stoffel, S., Scharf, S. J., Higuchi, R., Horn, G. T., Mullis, K. B. \& Erlich, H. A. (1988). Primer directed enzymatic amplification of DNA with a thermostable DNA polymerase. Science 239, 487-491.

Ward, D. M., Bateson, M. M., Weller, R. \& Ruff-Roberts, A. L. (1992). Ribosomal RNA analysis of microorganisms as they occur in nature. Adv Microb Ecol 12, 219-286.

Wallace, D. M. (1987). Large and small scale phenol extractions. Methods Enzymol 152, 33-41.

West, J. M., McKinley, I. G. \& Chapman, N. A. (1982). Microbes in deep geological systems and their possible influence on radioactive waste disposal. Radioactive Waste Management and the Nuclear Fuel Cycle 3, 1-15.

West, J. M., Christofi, N. \& McKinley, I. G. (1985). An overview of recent microbiological research relevant to the geological disposal of nuclear waste. Radioactive Waste Management and the Nuclear Fuel Cycle 6, 79-95.

Woese, C. R. (1987). Bacterial evolution. Microbiol Rev 51, 221-271.

Received 12 October 1993; revised 5 January 1994; accepted 14 January 1994. 